\title{
The fate of carbohydrates in the small and large intestines of the ruminant
}

By D. G. Armstrong and R. R. Smithard, Department of Agricultural Biochemistry, University of Newcastle upon Tyne

In the preceding paper of this symposium the extent to which ingested carbohydrates are fermented within the reticulo-rumen and the metabolic pathways involved in these degradative processes have been detailed. In this paper consideration will be given to the fate of carbohydrates leaving the rumen during their passage through the remainder of the alimentary tract. These carbohydrates, although mostly of feed origin, also include microbial carbohydrates; some may be digested in the small intestine by enzymes of animal origin and some may undergo microbial fermentation within the caecum. Post ruminal carbohydrate digestion has been reviewed by Armstrong \& Beever (r969), Ørskov (1969), Sutton (1971), Waldo (1973), Armstrong (1974) and Papasolomontos \& Wilkinson (1976).

\section{Nature and amount of carbohydrates escaping fermentation within the reticulo- rumen}

Carbohydrate passing to the small intestine comprises those portions of the plant structural carbohydrates, cellulose and hemicelluloses, and the plant storage polysaccharide, starch, which escape fermentation in the forestomach and the carbohydrates of protozoal and bacterial origin synthesized within the rumen and passing out of the forestomach in the digesta.

The proportion of structural carbohydrates in forage dry matter increases and their digestibilities decline with increasing maturity of the plant material (Waite et al. 1964). One consequence of these changes is that the amounts of structural carbohydrates which enter the small intestines depend on the maturity as well as the amount of forage fed. In vivo studies with sheep fed on fresh or dried grasses and legumes in the long or chopped form have shown that, irrespective of over-all digestibility of cellulose, which ranged from $0.5^{8}$ to 0.93 , most of that which is digested (at least 0.90 ) is degraded in the rumen (Beever et al. 1971; Thomson et al. 1972; Beever et al. 1972; Ulyatt \& MacRae, 1974; Thomson \& Beever, 1974); the same is true for the dry and lactating cow fed on rations high in chopped dried grass (Watson et al. 1972). However, when the forage fed to sheep is dried, ground and pelleted not only is over-all digestibility of cellulose depressed but also the proportion of digestible cellulose which disappears before the small intestine falls.

It is well known that cereal grain concentrate can depress the digestibility of the structural carbohydrates in mixed concentrate/forage rations (Raymond, 1969); such additions certainly affect the site of digestion (MacRae \& Armstrong, 1969). The results relating to cellulose, shown in Table $I$, illustrate these points. 
Table I. Cellulose intake, over-all digestibility and disappearance before the small intestine and in the caecum and colon of sheep given diets of hay and of hay and rolled barley*

Ration...

Cellulose intake $(\mathrm{g} / 24 \mathrm{~h})$

Apparent digestibility of cellulose

Disappearance of digestible cellulose:

Before small intestine In caecum and colon

$\begin{array}{ccc}\text { Hay } & \begin{array}{c}\text { Hay/barley } \\ (2: 1)\end{array} & \begin{array}{c}\text { Hay/barley } \\ (1: 2)\end{array} \\ 248.9 & 178.5 & 107.7 \\ 0.73 & 0.76 & 0.61 \\ & & \\ 0.91 & 0.84 & 0.5^{6} \\ 0.09 & 0.16 & 0.29\end{array}$

-MacRae \& Armstrong (1969).

The proportion of total digestible hemicelluloses, principally xylan, degraded in the rumen of sheep fed fresh or dried, chopped forage diets ranges from 0.60 to 0.80 unless the forage is of extremely high digestibility, when the proportion is 0.90 or more; as with cellulose, grinding and pelleting of dried forages lowers the proportion of the total digestible hemicellulose which is degraded in the rumen (Beever et al. 1971, 1972; Thomson et al. 1972; Ulyatt \& MacRae, 1974).

Digestion of water soluble carbohydrates present in forage plants is virtually complete within the rumen (Beever et al. 1971, 1972; Ulyatt \& MacRae, 1974).

In the studies with grain-fed animals summarized in Table 2 it can be seen that over-all digestibility of starch was complete. However, it must be emphasized that,

Table 2. Starch intake and digestibility in reticulo-rumen and over-all of diets fed to both sheep and cattle

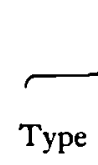

Grain

Form in Proportion

Barley:

Barley:

$\begin{array}{ll}\text { Rolled } & \text { I.00 } \\ \text { Whole } & 1 \cdot 00 \\ \text { Steam-flaked } & 0.68 \\ \text { Ground } & 0.58 \\ \text { Ground } & 0.78 \\ \text { Whole } & 0.90\end{array}$

Maize:

$\begin{array}{ll}\text { Ground } & 0.80 \\ \text { Steam-flaked } & 0.80 \\ \text { Ground } & 0.20 \\ \text { Ground } & 0.60 \\ \text { Ground } & 0.80\end{array}$

Sorghum:
Digestibility

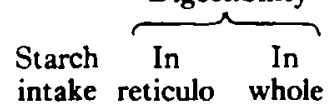

intake reticulo whole

Animal (g/24 h) rumen tract

$\begin{array}{lr}\text { Sheep } & 479 \\ \text { Sheep } & 573 \\ \text { Sheep } & 369 \\ \text { Cattle } & 2560 \\ \text { Cattle } & 3150 \\ \text { Cattle } & 185^{\circ}\end{array}$

Sheep 613

Sheep 626

Cattle 645

Cattle 1610

Cattle 2158

\subsection{2}

0.95

0.95

0.93

\subsection{8}

0.64

I. 00 MacRae \& Armstrong (1969)

- MacRae \& Armstrong ( 1969 )

I.00 Papasolomontos (1977)

- Thivend \& Journet (1968)

- Thivend \& Journet (1968)

Thivend \& Journet (1968)
Pavlicevic et al. (1972)

$\begin{array}{ll}0.78 & 1.00 \\ 0.96 & 1.00 \\ 0.59 & 1.00 \\ 0.50 & 0.99 \\ 0.70 & 0.99\end{array}$

Beever et al. (1970)

Beever et al. (1970)

Waldo et al. (1971)

Waldo et al. (1971)

Waldo et al. (1971)

$\begin{array}{lr}\text { Sheep } & 398 \\ \text { Sheep } & 373 \\ \text { Cattle } & 2070 \\ \text { Cattle } & 2290\end{array}$

0.89

0.89

0.42

0.83

$1 \cdot 00$

Papasolomontos (1977)

I.00 Papasolomontos (1977)

0.97 McNeill et al. (1971)

I. 00 McNeill et al. (1971) 
particularly with older cattle fed on rations high in whole maize grain, appreciable amounts of the grain may pass through the digestive tract undegraded (see Armstrong, 1974). From Table 2 it can also be seen that the proportion of barley grain starch fermented within the reticulo-rumen exceeds 0.90 for sheep and cattle unless the latter are given whole grain. When ground maize is fed to sheep and cattle appreciable amounts of starch escape rumen fermentation, but when steamflaked maize is fed to sheep, starch digestion within the rumen is virtually complete. Sorghum starch is effectively degraded in the rumen of sheep when the grain is rolled or steam-flaked but appreciable amounts escape fermentation in the reticulo-rumen of cattle when the sorghum is ground. Thus, it can be seen that certain types of grain processing may result in appreciable amounts of starch entering the small intestine. Since microbial $\alpha$-linked glucose polymer will assay along with dietary starch in ruminant digesta samples, it should be appreciated that any microbial starch swept out of the rumen in the digesta will lower the extent to which cereal grain starch is apparently fermented in the rumen.

Appreciable amounts of bacterial polysaccharides are synthesized within the rumen and enter the small intestine. Samples of bacteria harvested from the rumens of calves 4 to $6 \mathrm{~h}$ after feeding a ration comprising one-part roughage to one-part cereal-based concentrate, contained on average ( $\mathrm{g} / \mathrm{kg}$ bacterial dry matter) 140 glucose, as $a$-linked glucose polymer, 25 galactose and 25 other sugars, mainly rhamnose, ribose and mannose (McAllan \& Smith, 1974).

That the carbohydrate content of rumen bacteria is influenced by the diet of the host animal is very evident. Thus $a$-glucan content of rumen bacteria was lower $(25 \mathrm{~g} / \mathrm{kg}$ bacterial dry matter (DM)) in sheep and cows given an all roughage diet than in animals given a $1: 1$ roughage/concentrate diet $(70 \mathrm{~g} / \mathrm{kg}$ bacterial DM); the value increased further to $150 \mathrm{~g} / \mathrm{kg}$ bacterial DM when the ratio of concentrate to roughage was further widened to 7:3 (McAllan \& Smith, 1974). In subsequent studies with surgically modified steers fed on a ration containing hay and flaked maize, McAllan \& Smith (1976) reported that the mixed rumen bacteria which contained approximately I Io g $a$-linked glucose polymer/kg DM contributed some $60 \mathrm{~g} / \mathrm{d}$ of such polymer to the digesta entering the small intestine; they also noted that when a protein supplement was added to the diet the content of $\alpha$-linked glucose polymer in bacterial DM decreased. Carbohydrate content of rumen bacteria is also affected by time of sampling; thus in mixed rumen bacteria harvested from calves fed on dried forage the carbohydrate content varied from a peak value of about $140 \mathrm{~g} / \mathrm{kg}$ DM when sampled $0.5^{-1} \cdot 0 \mathrm{~h}$ after feeding to about $60 \mathrm{~g} / \mathrm{kg}$ DM $4 \mathrm{~h}$ after feeding (McAllan \& Smith, 1977).

The carbohydrate of rumen protozoa is composed mainly of glucose polymers with smaller proportions of xylose $(0.02-0.04)$, arabinose $(0.01-0.02)$ and mannose and galactose $(0.01)$ (Jouany \& Thivend, 1972). The carbohydrate content of rumen protozoa is influenced by the nature of the feed carbohydrate; on diets rich in cellulose, sucrose, inulin and starch the values were $98,165,265$ and $377 \mathrm{~g} / \mathrm{kg}$ DM respectively. On all diets except that high in cellulose, the carbohydrate content reached its maximum value some $2-3 \mathrm{~h}$ after feeding. 
In any consideration of the extent to which protozoal carbohydrate contributes to the carbohydrate entering the small intestine of the ruminant allowance must be made for the fact that only a small proportion $(0.06-0.29)$ of the protozoal DM present in the rumen liquor enters the small intestine (Weller \& Pilgrim, 1974). Harrison \& Beever (1979) have recently confirmed this finding.

\section{Fate of carbohydrates during passage of digesta through the small intestine}

Mammalian tissues do not synthesize enzymes with specific a-glucosidase activity. Thus it is not surprising to find that, in general, studies have shown virtually no cellulose digestion occurring during the passage of digesta through the small intestine; disappearance of hemicellulose also from the ruminant small intestine is very slight (Beever et al. 1971; Thomson et al. 1972; Beever et al. 1972; Ulyatt \& MacRae, 1974). It is noteworthy that studies with homogenates of intestinal mucosa from mature sheep (Hembry et al. 1967) and milk-fed calves (Coombe \& Siddons, 1973) have shown the presence of a cellobiase; however, the last-mentioned workers concluded from further experiments that this enzyme was identical to the lactase enzyme also shown to be present.

Enzymes involved in the hydrolysis of a-linked glucose polymers are the amylases and maltases of pancreatic juice and intestinal mucosa and oligo-r :6glucosidase of intestinal mucosa. Armstrong \& Beever (1969) reviewed the evidence then available concerning the occurrence of these enzymes in the small intestine of the adult ruminant; in the intervening period very few results have been added to the literature other than those relating to pre-ruminant animals with which this review is not concerned. Amylase and maltase activity are found both in pancreatic juices and in the intestinal mucosa of adult cattle and sheep (Hembry et al. 1967; Siddons, 1968; Chittenden et al. 1974; McNeill et al. 1974). The low activities of pancreatic maltase and of intestinal amylase relative to pancreatic amylase and intestinal maltase, respectively, suggests a greater importance of pancreatic amylase and intestinal maltase in starch hydrolysis. Isomaltase, with a $\mathrm{pH}$ optimum of $6 \cdot 0-6 \cdot 2$, an enzyme which hydrolyses the $1: 6$-glucosidic link, has been found in the intestinal mucosa of adult cows as well as milk-fed calves: the distribution patterns of isomaltase and maltase along the digestive tract are similar, being highest in the jejunum (Coombe \& Siddons, 1973) where the PH conditions are close to the optima for these enzymes (see Armstrong \& Beever, r969). Studies of pancreatic and intestinal carbohydrases in sucking and grown lambs have indicated that maltase may be the enzyme limiting the capacity for postruminal starch digestion but perhaps it should be noted that isomaltase was not assayed (Tacu, 1972). Mayes \& Ørskov (1974) have also emphasized the likely limiting activity of maltase. Of the starch which does enter the ruminant small intestine, appreciable amounts are removed before reaching the terminal ileum; for maize and barley, the proportions of $\alpha$-linked glucose polymer entering the small intestine which disappear therein were $0.85 \pm 0.05 \mathrm{I}$ and $0.77 \pm 0.056$ (see Armstrong, 1974), for oats the corresponding value was $0.95 \pm 0.050$ (D. G. Armstrong, unpublished results). There is evidence that the capacity of the small 
intestine to digest starch is limited, particularly when large amounts of it enter the duodenum (see Armstrong \& Beever, 1969; Mayes \& Ørskov, 1974).

Whether or not post-ruminal digestion of $\alpha$-linked glucose polymer leads to a significant uptake of glucose from the small intestine is at present the subject of conjecture. Net disappearance of starch from the small intestine does not alone indicate net absorption of glucose since it is likely that some microbial fermentation occurs in the distal part of the ileum. Indeed, the negative correlation between starch content and $\mathrm{pH}$ of digesta at the terminal ileum has been taken as evidence of microbial fermentation in the distal ileum (Mayes \& $\emptyset$ rskov, 1974).

The increase in portal blood glucose levels when maize replaced hay in the diets of weaned lambs (Thivend, 1973) and the elevated concentration of reducing sugar in the mesenteric vein draining the central third of the ileum when ground maize and molassine meal were added to the diets of dairy cows (Symonds \& Baird, 1975) have been taken as evidence of direct glucose absorption from the small intestine. Some further indirect evidence of glucose uptake in sheep fed on wheat, in contrast to dried lucerne, has been reported by Judson \& Leng (1973).

It is possible that some glucose disappearing from the small intestine may be metabolized to lactate by the intestinal mucosa (Wahle et al. 1972). Net formation of lactate in the portal drained viscera of fasted sheep receiving a ruminal infusion of volatile fatty acids could be accounted for by the net disappearance of endogenous glucose in these tissues (Weekes \& Webster, 1975); that lactate formation could not be so accounted for when sheep were fed on maize (Bensadoun et al. 1966) may have been due to absorption of glucose from the small intestine and its metabolism by those tissues.

The pentoses of microbial nucleic acids also constitute a small but significant supply of carbohydrate to the small intestine. The microbial nucleic acids undergo extensive degradation during the passage of digesta through the small intestine; the proportion of microbial nucleic acid $N$, entering the small intestine, which disappeared therein was approximately 0.80 in sheep fed on dried lucerne diets and reached as much as 0.95 when dried grass diets were fed (see Armstrong \& Hutton, 1975). The ribose-1-phosphate cleaved from the nucleic acids is then metabolized via ribose-5-phosphate to yield lactate (Wahle et al. 1971).

\section{Digestion in the caecum and colon}

Further fermentation of carbohydrate occurs in the caecum, the principal substrates being the residual amounts of cellulose, hemicellulose and $\alpha$-glucan which pass the ileo-caecal valve. The pathways of degradation appear similar to those occurring in the rumen; the products arising are VFA, methane, $\mathrm{CO}_{2}$ and microbial biomass. The proportions of individual VFA in the caecum in general resemble those in the rumen but caecal values tend to have higher proportions of acetate and of iso-acids; the former reflect the greater proportion of structural as distinct from non-structural polysaccharides entering the caecum whilst the latter suggest enhanced protein degradation in the caecum ( $\emptyset_{\text {rskov }}$ et al. 1970). In sheep fed on dried grass cubes VFA production in the caecum accounted for $5.3 \%$ of 
daily digestible energy intake (Faichney, 1969) and in sheep given lucerne chaff methane production in the caecum accounted for $10 \%$ of total methane production (Murray et al. 1976).

The results in Table 3 show that when sheep are fed on chopped grass, either fresh or dried, the proportion of digestible cellulose, which is fermented in the caecum, is about 0.10 ; with dried lucerne the proportion is higher. Two other factors which increase this value are the grinding and pelleting of the forage and the partial substitution of forage by cereal grain (see Table 3 ). A considerable

Table 3. Cellulose intake, over-all digestibility and disappearance in the caecum and colon of sheep receiving various diets

\begin{tabular}{|c|c|c|c|c|}
\hline Diet & $\begin{array}{l}\text { Cellulose } \\
\text { intake } \\
(\mathrm{g} / 24 \mathrm{~h})\end{array}$ & $\begin{array}{c}\text { Over-all } \\
\text { digestibility } \\
\text { of cellulose }\end{array}$ & $\begin{array}{l}\text { Proportion } \\
\text { of digestible } \\
\text { cellulose } \\
\text { disappearing } \\
\text { in caecum } \\
\text { and colon }\end{array}$ & Reference \\
\hline $\begin{array}{l}\text { Fresh grass (frozen) } \\
\text { Dried grass (chopped) } \\
\text { Wilted silage (chopped) }\end{array}$ & $\begin{array}{l}223 \\
224 \\
229\end{array}$ & $\begin{array}{l}0.75 \\
0.76 \\
0.77\end{array}$ & $\begin{array}{l}0.11 \\
0.08 \\
0.09\end{array}$ & $\begin{array}{l}\text { Beever et al. }(1970) \\
\text { Beever et al. }(1970) \\
\text { Beever et al. }(1970)\end{array}$ \\
\hline $\begin{array}{l}\text { Ryegrass (fresh) } \\
\text { White clover (fresh) }\end{array}$ & $\begin{array}{l}163 \\
109\end{array}$ & $\begin{array}{l}0.89 \\
0.87\end{array}$ & $\begin{array}{l}0.13 \\
0.12\end{array}$ & $\begin{array}{l}\text { Ulyatt \& MacRae (1974) } \\
\text { Ulyatt \& MacRae (1974) }\end{array}$ \\
\hline $\begin{array}{l}\text { Dried lucerne (chopped) } \\
\text { Dried lucerne (ground, pelleted) }\end{array}$ & $\begin{array}{l}274 \\
263\end{array}$ & $\begin{array}{l}0.58 \\
0.59\end{array}$ & $\begin{array}{l}0.18 \\
0.27\end{array}$ & $\begin{array}{l}\text { Thomson et al. (1972) } \\
\text { Thomson et al. (1972) }\end{array}$ \\
\hline $\begin{array}{l}\text { Dried grass (chopped) } \\
\text { Dried grass (pelleted) }\end{array}$ & $\begin{array}{l}302 \\
284\end{array}$ & $\begin{array}{l}0.87 \\
0.77\end{array}$ & $\begin{array}{l}0.05 \\
0.30\end{array}$ & $\begin{array}{l}\text { Beever et al. (1972) } \\
\text { Beever et al. (1972) }\end{array}$ \\
\hline $\begin{array}{l}\text { Hay } \\
\text { Hay/barley }(2: 1) \\
\text { Hay/barley }(I: 2)\end{array}$ & $\begin{array}{l}249 \\
179 \\
107\end{array}$ & $\begin{array}{l}0.73 \\
0.76 \\
0.61\end{array}$ & $\begin{array}{l}0.09 \\
0.16 \\
0.29\end{array}$ & $\begin{array}{l}\text { MacRae \& Armstrong ( } 1969 \text { ) } \\
\text { MacRae \& Armstrong (1969) } \\
\text { MacRae \& Armstrong (1969) }\end{array}$ \\
\hline
\end{tabular}

Table 4. Cellulose intake, over-all digestibility and disappearance in the caecum and colon of sheep receiving various diets

Diet

Fresh grass (frozen)

Dried grass (chopped)

Wilted silage (chopped)

Ryegrass (fresh)

White clover (fresh)

Dried lucerne (chopped)

Dried lucerne (ground, pelleted)

Dried grass (chopped)

Dried grass (ground, pelleted)

$\begin{array}{ccc}\begin{array}{c}\text { Hemi- } \\ \text { cellulose } \\ \text { intake } \\ (\mathbf{g} / \mathbf{2 4} \mathrm{h})\end{array} & \begin{array}{c}\text { Over-all } \\ \text { digestibility } \\ \text { of hemi- } \\ \text { cellulose }\end{array} & \begin{array}{c}\text { Proportion } \\ \text { of digestible } \\ \text { hemi- } \\ \text { cellulose } \\ \text { disappearing } \\ \text { in the caecum } \\ \text { and colon }\end{array} \\ 115 & 0.59 & 0.25 \\ 115 & 0.58 & 0.34 \\ 106 & 0.60 & 0.31 \\ 34 & 0.84 & 0.13 \\ 109 & 0.76 & 0.15 \\ 109 & 0.52 & 0.31 \\ 183 & 0.55 & 0.41 \\ 175 & 0.74 & 0.09 \\ 18 & 0.73 & 0.34\end{array}$

Reference

Beever et al. (1970)

Beever et al. (1970)

Beever et al. (1970)

Ulyatt \& MacRae (1974)

Ulyatt \& MacRae (1974)

Thomson et al. (1972)

Thomson et al. (1972)

Beever et al. (1972)

Beever et al. (1972) 
proportion of digestible hemicellulose, also, may be fermented in the caecum and again, grinding and pelleting increase this value (Table 4 ).

The proportion of $a$-linked glucose polymer which remains to be fermented in the hind-gut is normally very small but when high levels of ground maize are fed to cattle the caecum assumes increasing significance (Table 5).

Table 5. $\alpha$-Glucan intake, over-all digestibility and disappearance in the caecum and colon of sheep and of cattle fed on grain or grain/hay diets

\begin{tabular}{|c|c|c|c|c|}
\hline \multicolumn{5}{|c|}{ Sheep } \\
\hline Diet & $\begin{array}{c}\text { a-glucan } \\
\text { intake } \\
\text { (g/24 h) }\end{array}$ & $\begin{array}{l}\text { Over-all } \\
\text { digestibility } \\
\text { of } a \text {-glucan }\end{array}$ & $\begin{array}{c}\text { Proportion } \\
\text { of digestible } \\
\text { a-glucan } \\
\text { disappearing } \\
\text { in the } \\
\text { caecum and } \\
\text { colon }\end{array}$ & Reference \\
\hline $\begin{array}{l}\text { Flaked barley/hay }(7: 3) \\
\text { Rolled barley/hay }(7: 3) \\
\text { Rolled barley/hay }(2: 1) \\
\text { Rolled barley/hay }(1: 1)\end{array}$ & $\begin{array}{l}370 \\
35^{\circ} \\
321 \\
171\end{array}$ & $\begin{array}{l}1.00 \\
1.00 \\
1.00 \\
1.00\end{array}$ & $\begin{array}{ll}0.003 & \mathbf{P} \\
0.003 & \mathbf{P} \\
0.004 & 1 \\
0.004 & \mathbf{N}\end{array}$ & $\begin{array}{l}\text { Papasolomontos (1977) } \\
\text { Papasolomontos (1977) } \\
\text { MacRae \& Armstrong (1969) } \\
\text { MacRae \& Armstrong (1969) }\end{array}$ \\
\hline $\begin{array}{l}\text { Steam-flaked maize } \\
\text { Ground maize } \\
\text { Rolled maize/hay }(7: 3) \\
\text { Steam-flaked maize/hay }(7: 3) \\
\text { Steam-flaked maize/hay }(2: 1) \\
\text { Rolled sorghum/hay }(7: 3) \\
\text { Steam-flaked sorghum/hay }(7: 3)\end{array}$ & $\begin{array}{l}626 \\
613 \\
372 \\
367 \\
345 \\
398 \\
373\end{array}$ & $\begin{array}{l}1 \cdot 00 \\
1 \cdot 00 \\
1 \cdot 00 \\
1 \cdot 00 \\
1 \cdot 00 \\
1 \cdot 00 \\
1 \cdot 00\end{array}$ & $\begin{array}{l}0.002 \\
0.001 \\
0.011 \\
0.004 \\
0.004 \\
0.007 \\
0.016\end{array}$ & $\begin{array}{l}\text { Beever et al. (1970) } \\
\text { Beever et al. (1970) } \\
\text { Papasolomontos (1977) } \\
\text { Papasolomontos (1977) } \\
\text { MacRae \& Armstrong (1969) } \\
\text { Papasolomontos (1977) } \\
\text { Papasolomontos (1977) }\end{array}$ \\
\hline \multicolumn{5}{|c|}{ Cattle } \\
\hline $\begin{array}{l}\text { Ground maize/lucerne hay }(1: 5) \\
\text { Ground maize/lucerne hay }(2: 3) \\
\text { Ground maize/lucerne hay }(3: 2) \\
\text { Ground maize/lucerne hay }(4: 1)\end{array}$ & $\begin{array}{l}1002 \\
1948 \\
2438 \\
2684\end{array}$ & $\begin{array}{l}0.99 \\
0.99 \\
0.98 \\
0.98\end{array}$ & $\begin{array}{l}0.014 \\
0.032 \\
0.054 \\
0.113\end{array}$ & $\begin{array}{l}\text { Karr et al. (1966) } \\
\text { Karr et al. (1966) } \\
\text { Karr et al. (1966) } \\
\text { Karr et al. (1966) }\end{array}$ \\
\hline
\end{tabular}

The extent of energy digestion in the caecum and colon may vary quite widely; in studies where sheep were fed on a variety of forages the proportion of total digestible energy digested in the caecum and colon ranged from 0.04 to 0.28 (Beever et al. 1971, 1972; Thomson et al. 1972). It can be calculated from the results of Beever et al. (1972) that for an early cut dried grass fed to sheep the proportion of energy digested in the caecum, which was supplied as cellulose and hemicellulose, increased from 0.37 when fed chopped to more than $0.6 \mathrm{I}$ when the diet was fed pelleted.

Nutritional implications to the host animal of post-ruminal carbohydrate fermentation

Supply of amino acids to the host animal. The fact that under certain dietary regimes considerable amounts of potentially degradable carbohydrate escape fermentation in the reticulo-rumen reduces microbial amino acid supply to the host 
animal (Papasolomontos, 1977). The entry of fermentable carbohydrate into the small intestine implies reduced synthesis of rumen microbial biomass and hence less microbial protein entering the small intestine. Whether such carbohydrate is $\alpha$ glucan and is digested in the small intestine or undergoes microbial fermentation in the caecum is immaterial since there is no evidence that amino acids incorporated into microbial protein synthesized in the caecum are subsequently released and absorbed from the large intestine. In this laboratory Elliott \& Little (1977) infused $\mathrm{Na}_{2}{ }^{35} \mathrm{SO}_{4}$ into the terminal ileum of sheep fed on a pelleted, dried grass diet. Although $\left({ }^{35} \mathrm{~S}\right)$ cyst(e)ine activity was abundantly present in the faeces as microbial protein none was detected in blood or wool.

It will be appreciated that the main categories of feed to which the above phenomena apply are those containing high proportions of ground maize, a high proportion of dried forage, especially when ground and pelleted or, thirdly, where high levels of grain in forage/grain rations depress cellulose digestion in the rumen and, possibly, over all.

The fermentation of residual carbohydrate in the caecum, leading to the synthesis of microbial biomass therein and its excretion in the faeces, provides at

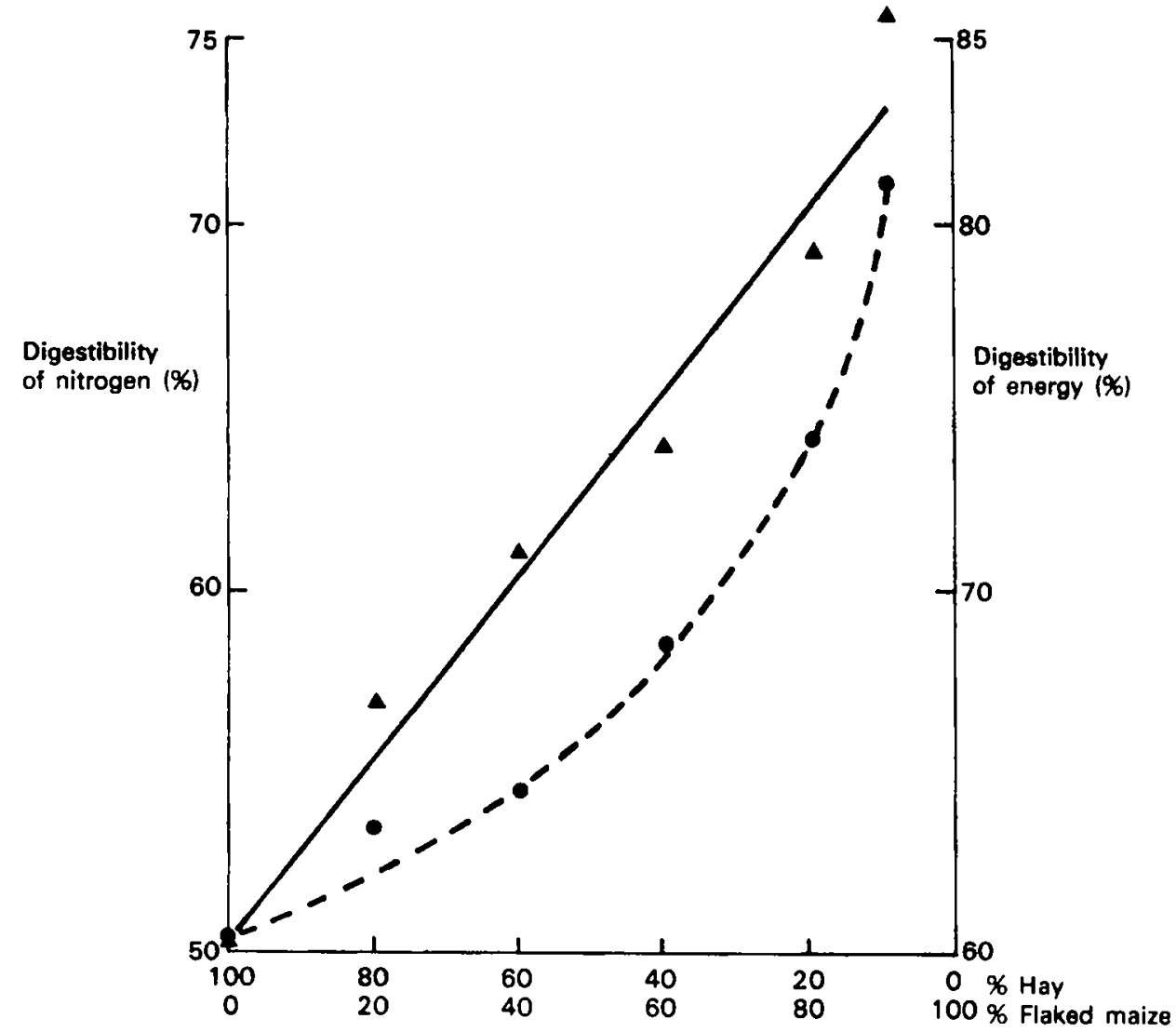

Fig. I. Effect of diet on $(\Delta,-)$ apparent digestibility of nitrogen and $(0,---)$ energy, for cattle on a high level of feeding (Blaxter \& Wainman, 1964). 


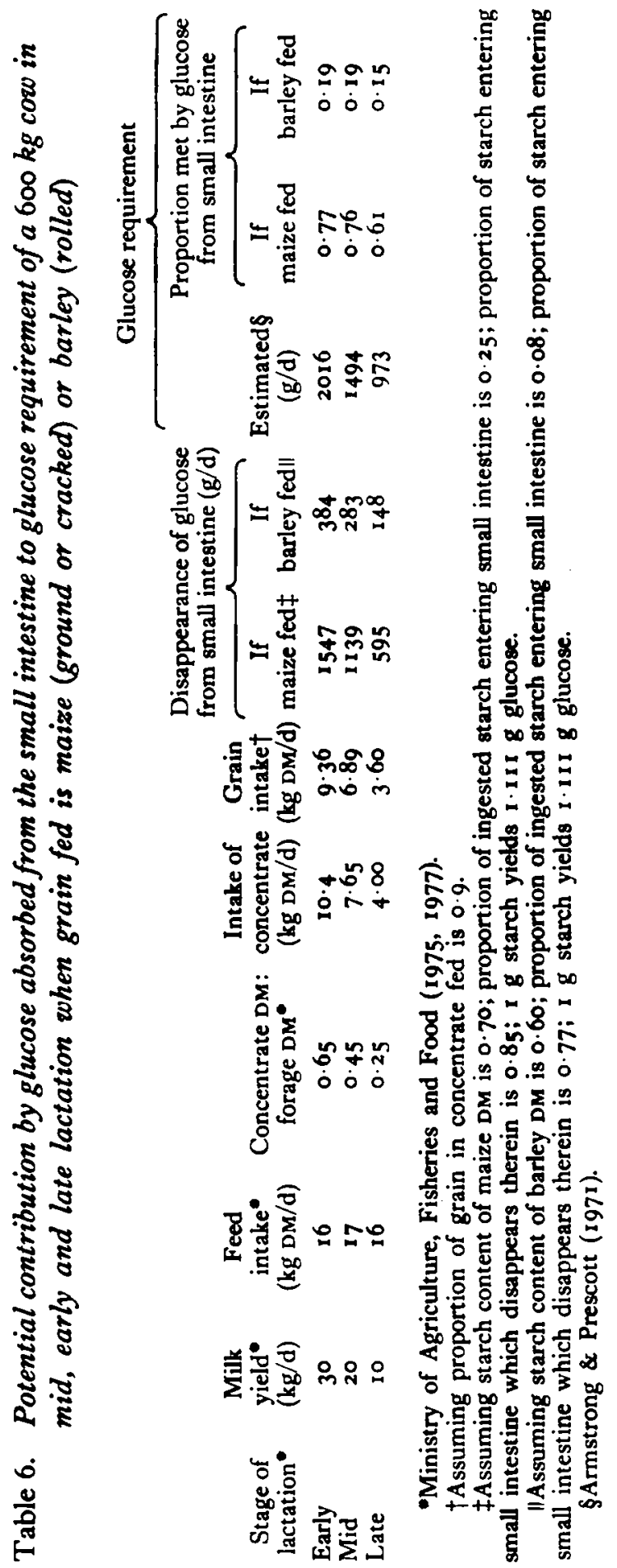


least a partial understanding of the phenomenon known as the associative effect of feeds in digestion. This is well illustrated by reference to the results of Blaxter \& Wainman (1964) who gave diets ranging from all hay to virtually all flaked maize to cattle. Fig. I shows the information relating to over-all digestibility of energy and of $\mathbf{N}$ for all the rations fed. It can be seen that over-all digestibility of energy is linearly related to the proportions of the two components present in the feed; however, the values for $\mathbf{N}$ digestibility are lower than those which would be expected from those of the two feeds fed individually, a reflection of the increased microbial $\mathrm{N}$ synthesized in the caecum as a result of a starch-induced reduction in digestion of cellulose in the reticulo-rumen.

Supply of glucose to the host animal. A second nutritional consequence of postruminal digestion of carbohydrates relates to the extent to which $\alpha$-glucan digested in the small intestine contributes to the glucose requirement of the host animal. The potential contribution to the glucose requirement of the high yielding dairy cow at various stages of lactation by glucose arising from digestion of $\alpha$-glucan in the small intestine has been assessed in Table 6 . From this table it can be seen that

Table 7. Calculation of potential contribution of bacterial a-glucan to glucose entry into the small intestine of $600 \mathrm{~kg}$ cow in early lactation

Intake of $600 \mathrm{~kg} \mathrm{cow}$, yielding $30 \mathrm{~kg} \mathrm{milk} / \mathrm{d}$

$$
\begin{aligned}
& =16 \times 0.92 \\
& =14.72 \times 0.75
\end{aligned}
$$

$=16 \mathrm{~kg} \mathrm{DM} / \mathrm{d}$

$=14.72 \mathrm{~kg} \mathrm{OM} / \mathrm{d}^{*}$

$=11.04 \mathrm{~kg} \mathrm{DOMI} / \mathrm{d} \dagger$

$\therefore \quad \mathrm{OM}$ actually digested in reticulo-rumen Yield of microbial-N $=11 \cdot 04 \times 24 \cdot 3$

$=\mathrm{II} \cdot 04 \mathrm{~kg} / \mathrm{d} \ddagger$

$=268 \cdot 3 \mathrm{~g} / \mathrm{d} \|$

$\therefore$ Bacterial DM entering small intestine

$$
=\frac{268 \cdot 3}{62 \cdot 7}=4.28 \mathrm{~kg} / \mathrm{d} \S
$$

\begin{tabular}{|c|c|}
\hline $\begin{array}{l}\text { For maize-fed cow, whose grain intake } \\
\alpha \text {-glucan entering small intestine }\end{array}$ & $\begin{array}{l}=9.36 \mathrm{~kg} \mathrm{DM} / \mathrm{d} \uparrow \\
=9.36 \times 0.70 \times 0.25 \\
=1638 \mathrm{~g} / \mathrm{d}\end{array}$ \\
\hline $\begin{array}{l}\text { For barley-fed cow, whose grain intake } \\
\alpha \text {-glucan entering small intestine }\end{array}$ & $\begin{array}{l}=9.36 \mathrm{~kg} \mathrm{DM} / \mathrm{d} q \\
=9.36 \times 0.60 \times 0.08 \\
=449 \mathrm{~g} / \mathrm{d}\end{array}$ \\
\hline
\end{tabular}

$\therefore \alpha$-glucan of bacterial origin entering small intestine

$$
\begin{aligned}
& =4.28 \times 136 \S \\
& =582 \mathrm{~g} / \mathrm{d}
\end{aligned}
$$

- Assume organic matter (OM) in feed is $0.92 \mathrm{DM}$.

$\dagger$ Assume digestibility of $O M$ in feed is 0.75 .

†For high barley rations fed to cattle, the ratio of OM digested in the reticulo-rumen to digestible organic matter intake is 1.00 (P. Meggison and D. G. Armstrong, unpublished observations).

$\|$ Yield of microbial-N $/ \mathrm{kg} \mathrm{OM}$ actually digested in the reticulo-rumen $=24.03 \mathrm{~g} / \mathrm{kg}$.

\$Assume that composition of mixed rumen bacteria (McAllan \& Smith, 1977) is representative of that entering small intestine:

$$
\begin{array}{cc}
\text { crude protein } & \mathrm{g} / \mathrm{kg} \mathrm{DM} \\
\therefore \quad \mathrm{N} & 392 \\
\therefore \text {-glucan } & 62 \cdot 7 \\
13^{6}
\end{array}
$$

ISee footnotes to Table 6. 
if the major grain source were maize and if the $\alpha$-glucan disappearing in the small intestine were absorbed as glucose it might contribute some $6 \mathrm{I}-77 \%$ of the overall glucose requirement. With barley grain on the other hand, such glucose would make a much smaller contribution to the glucose requirement (15-19\%). With reference to the feeding of barley grain the calculations shown in Table 7 suggest that all the $\alpha$-glucan entering the small intestine may be of microbial origin.

From consideration of the glucose requirement of sheep in late pregnancy (Armstrong, 1965) and calculations similar to those of Table 6 it is clear that the inclusion of a high level of maize grain in their diets could make a very material contribution to over-all glucose requirement and also to that of early lactation.

The potential significance of glucose entering the small intestine has been given added weight by the recent demonstration by Leng et al. (1978) of the capacity of exogenous glucose, supplied as an infusion into the duodenum, to increase the efficiency of utilization of nutrients. On a basal diet of $(\mathrm{g} / \mathrm{kg})$ chaff 480 , sugar 480 , urea 40 plus minerals, a supply of glucose to the small intestine improved both growth rate and feed conversion ratio; the effect was enhanced still further by incorporation of fishmeal $(60 \mathrm{~g} / \mathrm{kg})$ into the diet. The authors speculate that the exogenous glucose achieves its effect by sparing amino acids from deamination.

\section{REFERENCES}

Armstrong, D. G. (1965). In Carbohydrate metabolism in ruminants and energy supply. Proceedings 2nd International Symposium on the Physiology of Digestion in the Ruminant. [R. W. Dougherty, editor] p. 272, Washington: Butterworths.

Armstrong, D. G. (1974). In Cereal supply and utilization, p. 21, Tech. Publs U.S. Feed Grains Council, London.

Armstrong, D. G. \& Beever, D. E. (1969). Proc. Nutr. Soc. 28, 121.

Armstrong, D. G. \& Hutton, K. (1975). In Digestion and Metabolism in the Ruminant, [I. W. McDonald \& A. C. I. Warner, editors] pp. 432-447. Armidale: The University of New England Publishing Unit.

Armstrong, D. G. \& Prescott, J. H. D. (1971). In Lactation, Proceedings of Seventeenth Easter School in Agricultural Science, 1970. p. 349. [I. R. Falconer, editor] London: Butterworths.

Beever, D. E., Coelho da Silva, J. F. \& Armstrong, D. G. (1970). Proc. Nutr. Soc. 29, 43A.

Beever, D. E., Coelho da Silva, J. F., Prescott, J. H. D. \& Armstrong, D. G. (1972). Br. F. Nutr. 28,347 .

Beever, D. E., Thomson, D. J., Pfeffer, E. \& Armstrong, D. G. (1971). Br. Y. Nutr. 26, 123.

Bensadoun, A., Cushman, L. L. \& Reid, J. T. (1966). Fedn Proc. Fedn Am. Socs exp. Biol. 25, 543 .

Blaxter, K. L. \& Wainman, F. W. (1964). F. agric. Sci. 63, I13.

Chittenden, L. W., Mitchell, G. E. Jr., Tucker, R. E. \& Schelling, G. T. (1974). J. Anim. Sci. 38, 232.

Coombe, N. B. \& Siddons, R. C. (1973). Br. F. Nutr. 30, 269.

Elliott, R. \& Little, D. A. (1977). Aust. F. biol. Sci. 30, 203.

Faichney, G. J. (1969). Aust. F. agric. Res. 20, 491.

Harrison, D. G., Beever, D. E. \& Osbourn, D. F. (1979). Br. J. Nutr. 41, 521 .

Hembry, F. G., Bell, M. C. \& Hall, R. F. (1967). f. Nutr. 93, 175 .

Jouany, J. P. \& Thivend, P. (1972). Ann. Biol. anim. Bioch. Biophys. 12 (4), 673.

Judson, G. J. \& Leng, R. A. (1973). Br. F. Nutr. 29, 159.

Karr, M. R., Little, C. O. \& Mitchell, G. E. Jr. (1966). F. Anim. Sci. 25, 652.

Leng, R. A., Economides, S. \& Ball, F. M. (1978). Proc. Aust. Soc. Anim. Prod. 12, 134.

McAllan, A. B. \& Smith, R. H. (1974). Br. F. Nutr. 31, 77.

McAllan, A. B. \& Smith, R. H. (1976). Br. F. Nutr. 36, 5 II. 
McAllan, A. B. \& Smith, R. H. (1977). Br. F. Nutr. 37, 55.

McNeill, J. W., Potter, G. D. \& Riggs, J. K. (1971). J. Anim. Sci. 33, 137 I.

McNeill, J. W., Tucker, R. E., Schelling, G. T. \& Mitchell, G. E. Jr. (1974). J. Anim. Sci. 38, 232, Abstr.

MacRae, J. C. \& Armstrong, D. G. (1969). Br. F. Nutr. 23, 377.

Mayes, R. W. \& Ørskov, E. R. (1974). Br. F. Nutr. 32, 143.

Ministry of Agriculture Fisheries \& Food (1975). Tables of Feed Composition and Energy Allowances for Ruminants. London: H.M. Stationery Office.

Ministry of Agriculture Fisheries \& Food (1977). Complete Diet Feeding of Dairy Cows. London: H.M. Stationery Office.

Murray, R. M., Bryant, A. M. \& Leng, R. A. (1976). Br. f. Nutr. 24, 671.

Orskov, E. R. (196g). Rev. Cubana Cienc. Agric. (Eng. Edit.) 3, I.

Ørskov, E. R., Fraser, C., Mason, V. C. \& Mann, S. D. (1970). Br. F. Nutr. 24, 671.

Papasolomontos, S. A. (1977). Digestion of heat-processed cereals by the adult sheep. PhD Thesis, University of Newcastle upon Tyne.

Papasolomontos, S. A. \& Wilkinson, J. I. D. (1976). In Optimising the utilization of cereal energy by cattle and pigs, p. 31, Tech. Pub. U.S. Feed Grains Council, London.

Pavlicevic, A., McLeod, N. A. \& Kay, M. (1972). Proc. Nutr. Soc. 31, 56A.

Raymond, W. F. (1969). Adv. Agron. 21, I.

Siddons, R. C. (1968). Biochem. F. 108, 839 .

Sutton, J. D. (1971). Proc. Nutr. Soc. 30, 243.

Symonds, H. W. \& Baird, G. D. (1975). Br. Vet. f. 131, (1) 17-22.

Tacu, A. (1972). Lucrările Stüntifice ale Institutului de Cercetări pentru Nutritie Animală I, 34I. Nutr. Abst. \& Rev. 44, 520, Abstr. 4609.

Thivend, P. (1973). Proc. Nutr. Soc. 33, 7 A.

Thivend, P. \& Journet, M. (I968). Ann. Biol. anim. Bioch. Biophys. 8, 449.

Thomson, D. J. \& Beever,.D. E. (1974). Proc. 5th General Meeting Grassland Federation 1973, Uppsala, Vaxtodling 28, 107 .

Thomson, D. J., Beever, D. E., Coelho da Silva, J. F. \& Armstrong, D. G. (1972). Br. J. Nutr. 28, 347.

Ulyatt, M. J. \& MacRae, J. C. (1974). F. agric. Sci., Camb. 82, 295.

Wahle, K. W. J., Armstrong, D. G. \& Sherratt, H. S. A. (1971). Comp. Biochem. Physiol. 38B, 5. Wahle, K. W. J., Weekes, T. E. C. \& Sherratt, H. S. A. (1972). Comp. Biochem. Physiol. 4IB, 759. Waite, R., Johnstone, M. J. \& Armstrong, D. G. (1964). f. agric. Sci., Camb. 62, 391.

Waldo, D. R. (1973). J. Anim. Sci. 37, 1062.

Waldo, D. R., Keys, J. E. Jr. \& Gordon, C. H. (1971). F. Anim. Sci. 33, 304.

Watson, M. J., Savage, G. P., Brown, L. \& Armstrong, D. G. (1 972). Proc. Nutr. Soc. 31, 99 A.

Weekes, T. E. C. \& Webster, A. J. F. (1975). Br. J. Nutr. 33, 425.

Weller, R. A. \& Pilgrim, A. F. (1974). Br. F. Nutr. 32, 341. 